\title{
PENERAPAN COSO ERM INTEGRATED FRAMEWORK DALAM MENDUKUNG AUDIT FORENSIK UNTUK MENANGGULANGI TINDAKAN KECURANGAN
}

\author{
Soegeng Soetedjo ${ }^{1)}$, Ahmad Sugianto ${ }^{2)}$ \\ Ketua Badan Pengawas Internal Universitas Airlangga ${ }^{1)}$ \\ Magister Akuntansi, Fakultas Ekonomi dan Bisnis, Universitas Airlangga ${ }^{2)}$ \\ Kampus C Mulyorejo, Surabaya, Indonesia \\ 2) E-mail: ahsugianto@yahoo.co.id
}

\begin{abstract}
Abstrak
Hal-hal yang menjadi perhatian investigator yang paling utama adalah pada pengendalian internal dalam organisasi. Pengendalian internal ini menjadi hal yang sangat penting dan berdampak besar terhadap tindakan kecurangan yang terjadi selaras dengan tingkat risiko dalam mencapai tujuan organisasi. Pada tahun 2016 COSO telah menerbitkan COSO ERM Integrated Framework. Framework tersebut mengembangkan lebih lanjut pada pengendalian internal dengan memberikan perhatian utama pada subjek ERM yang lebih luas. Kesimpulannya integrasi antara lima komponen pengendalian internal dengan ERM memberikan jaminan bagi manajemen bahwa tujuan organisasi akan tercapai secara efektif dan efisien termasuk mencegah terjadinya fraud.
\end{abstract}

Kata kunci: pengendalian internal, COSO ERM Integrated Framework, Pencegahan Kecurangan. 


\section{Latar belakang}

Banking Dewasa ini perkembangan auditor internal telah mengalami suatu Quatum Leap dari semula hanya sebagai watchdog telah bergeser menjadi konsultan dan katalisator. Di dalam peran watch dog ini, auditor internal cenderung hanya berusaha mencari-cari apa yang salah dalam suatu operasional organisasi dan memberikan sanksi yang setimpal bila diketahui, sehingga auditee selalu menjadi was-was dan tertekan bilamana ada kegiatan pemeriksaan. Sebagai konsultan, internal auditor menjadi lebih berdaya guna dan dibutuhkan oleh auditee untuk mengatasi permasalahan - permasalahan opeasional yang timbul. Sedangkan sebagai katalisator, internal auditor diharapkan dapat memberikan penjaminan (assurance) atas suatu operasionalbisnis yang berjalan sehingga organisasi tetap berada pada on the track sesuai tujuan dan strategi organisasi yang telah ditetapkan.

Peran internal auditor ini tidak semudah membalikkan telapak tangan dalam pengaplikasiannya. Internal auditor menghadapi banyak tantangan baik yang datangnya dari dalam organisasi itu sendiri maupun dari luar organisasi. Tantangan dari dalam organisasi dapat berupa sikap apriori dari auditee, sehingga tidak mau bekerjasama dengan baik, dan juga kebijakankebijakan organisasi yang terkadang tidak sesuai dengan prinsip tatakelola yang baik. Adapun tantangan dari luar organisasi dapat berupa kewajiban untuk memenuhi kualifikasi yang disyaratkan oleh Standar Profesi Audit Internal yang diterbitkan oleh Asosiasi Auditor Internal maupun ketentuan perundangan yang disyaratkan seperti ketentuan yang mengatur tatakelola organisasi yang baik, dimana kedudukan auditor internal beradap ada posisi yang independen.

Dengan memperhatikan berbagai tantangan yang ada sangat dimungkinkan menimbulkan berbagai tindakan kecurangan. Tindakan kecurangan ini adakalanya tidak dapat teridentifikasi karena lemahnya pengendalian internal (internal control) di dalam organisasi, sehingga dimanfaatkan oleh oknum-oknum tertentu untuk mengambil keuntungan pribadi, dan hal ini dapat terjadi mulai dari level paling bawah sampai level paling tinggi di organisasi.

Penanggulangan tindakan kecurangan tidak bisa dilepaskan dari peran katalisator internal auditor, untuk terus memberikan pengawalan kepada organisasi untuk mencapai tujuannya. Dalam proses pengawalan ini bilamana ditemukan adanya indikasi kecurangan maka internal auditor berubah perananannya menjadi investigator kecurangan (fraud investigator). Hal ini selaras dengan yang diungkap oleh Standar Profesi Audit Internal 3100.2 dan 3100.3 yang diterbitkan oleh Asosiasi Auditor Internal (2016) yang menyatakan bahwa internal auditor mempunyai kewajiban untuk mengidentifikasi ketidakpatuhan yang terjadi di organisasi dan risiko kecurangan yang ditimbulkannya, selanjutnya melaporkan atas ketidakpatuhan terhadap perundang-undangan tersebut kepada pihak-pihak yang berwenang.

Sebagai investigator kecurangan, dalam menjalankan keahlian profesionalnya, internal auditor melakukan audit forensik (forensic audit) untuk mengurai benang kusut atas permasalahan-permasalahan kecurangan yang terjadi, sehingga diperoleh bukti yang kuat dan berkekuatan hukum positif sehingga dapat dipertanggungjawabkan di pengadilan bilamana diperlukan. Berkekuatan hukum positif maksudnya adalah hukum yang berlaku saat ini sebagai landasan hukum atas suatu tindakan kecurangan tertentu yang diproses melalui pengadilan. Lee et al. (2009:234) memaparkan 3 hal yang seharusnya menjadi perhatian investigator kecurangan, yaitu:

a. Adanya kejanggalan transaksi atas suatu transaksi yang terjadi, frekuensi keterjadian, tempat, jumlah, ataupun pihak-pihak lain yang berhubungan.

b. Pengendalian internal yang tumpang tindih (internal control overriden).

c. Rendahnya motivasi dan moral karyawan.

Lee et al. (2009) telah memaparkan dengan jelas dan terperinci berbagai kondisi yang berpotensi menimbulkan tindakan kecurangan, dan diakui pula bahwa sebagian besar kasus kecurangan berakhir dengan proses pengadilan (litigation). Proses pengadilan ini menjadi solusi terakhir bilamana proses 
rekonsiliasi internal organisasi tidak bias dipenuhi dan kasus yang diungkap merupakan kasus yang vital bagi organisasi dan menyalahi perundang-undangan yang berlaku.

Hal-hal yang menjadi perhatian investigator kecurangan yang telah dipaparkan oleh Lee et al. (2009), yang paling utama adalah pada pengendalian internal yang tumpang tindih. Pengendalian internal ini menjadi hal yang sangat penting dan berdampak besar terhadap tindakan kecurangan yang terjadi, semakin lemah pengendalian internal organisasi maka potensi tindakan kecurangan juga semakin besar dan sebaliknya. Adapun tingkat risiko juga selaras dengan kuat ataupun lemahnya pengendalian internal organisasi.

Keadaan di atas yang mendasari COSO (The Committee of Sponsoring Organization of The Tradway Commissions) menyusun model pengendalian internal yang handal beserta risiko dan tata kelola organisasi. Setiap tahunnya COSO terus melakukan pembaharuan, pembaharuan terbaru pada tahun 2016 dengan diterbitkannya COSO ERM Integrated Framework. Pada pembaharuan yang terbaru ini, framework tersebut mengembangkan lebih lanjut pada pengendalian internal dengan memberikan perhatian utama pada subjek ERM yang lebih luas, oleh karena itu, dengan penerapan COSO ERM Integrated Framework memberikan harapan baru bagi organisasi untuk lebih meningkatkan kehandalan pengendalian internalnya, sehingga produktivitas dan profitabilitas organisasi meningkat. Hal ini sekaligus juga membantu investigator kecurangan untuk menjalankan audit forensik secara lebih komprehensif dan tepat sasaran dengan memperhatikan risiko dan tata kelola sesuai dengan prinsip 3E (ekonomis, efektif, efisien), sehingga segala tindakan kecurangan dalam organisasi dapat diidentifikasi lebih dini dan segera dapat ditanggulangi.

\subsection{Rumusan Masalah}

Tergambar secara jelas bahwa penerapan COSO ERM Integrated Framework meliputi berbagai aspek komprehensif terutama atas fungsi pengendalian internal dan proses manajemen risikonya, yang dapat dimanfaatkan untuk mendukung kegiatan audit forensik. Dengan adanya integrasi pemanfaatan framework ini diharapkan tindakan kecurangan yang terjadi di organisasi dapat dicegah secara dini sebelum timbul tindakan kecurangan derivatifnya, atau bila sudah terjadi dan mempunyai dampak yang signifikan maka dapat dilakukan penindakan secara hukum sesuai dengan peraturan yang berlaku.Atas dasar ini, maka pertanyaan yang muncul adalah bagaimana penerapan COSO ERM Integrated Framework dalam mendukung audit forensik untuk mencegah tindakan kecurangan yang terjadi pada organisasi. Tulisan ini mencoba mengintegrasikan antara sistem pengendalian internal dan ERM (COSO ERM Integrated Framework untuk pencegahan kecurangan keuangan (fraud) di dalam organisasi.

\subsection{Tujuan Penulisan}

Merujuk pada pertanyaan di atas, tulisan ini bermaksud menggali dan mengeksplorasi penerapan COSO ERM Integrated Framework dalam mendukung audit forensik untuk mencegah tindakan kecurangan yang terjadi pada perusahaan.

\subsection{Manfaat Penulisan}

Merujuk pada tujuan penulisan ini diharapkan tulisan ini dapat memberikan manfaat sebagai berikut:

a. Manfaat teoritis

Menambah perbendaharaan akademis dengan memberikan gambaran praktis atas diterapkannya COSO ERM Integrated Framework dalam mendukung audit forensik untuk mencegah tindakan kecurangan yang terjadi pada perusahaan. Selanjutnya dapat dikembangkan menjadi suatu topik bahasan tertentu untuk dapat menambah pemahaman teoritis audit internal.

b. Manfaat Empiris

Menyajikan gambaran hasil penerapan COSO ERM Integrated Framework dalam mendukung pelaksanaan audit forensik untuk mencegah tindakan kecurangan yang terjadi di perusahaan. Selanjutnya dapat mendorong penelitian atas risiko dan tatakelola perusahaan yang termaktub dalam COSO ERM Integrated Framework yang tidak dieksplorasi dalam 
tulisan penelitian ini.

\section{c. Manfaat Praktis}

Sebagai bahan masukan bagi perusahaan agar dapat memperoleh manfaat atas penerapan COSO ERM Integrated Framework dan pemutakhiran keahlian audit forensik sesuai kapabilitas yang ada bagi para personil Satuan Pengawasan Internal (Auditor Internal), sehingga berbagai potensi ataupun post-event tindakan kecurangan dapat segera ditanggulangi.

\section{Kerangka pemikiran}

Penulisan mendasarkan penerapan COSO ERM Integrated Framework dengan fokus pada Internal Control-Integrated Framework. Dalam framework ini dibagi ke dalam 3 kategori penjaminan (assurance) pengendalian internal, yaitu efektivitas dan efisiensi operasi, reliabilitas pelaporan keuangan, dan kepatuhan terhadap hukum dan perundangan. Ketiga kategori tersebut digunakan untuk mendukung pelaksanaan audit forensik atas suatu tindakan pencegahan kecurangan yang terjadi di perusaahaan, sehingga dapat segera ditanggulangi secara lebih dini ataupun post-event. Berikut kerangka penelitian yang digunakan dalam penelitian ini:

\section{Gambar 1}

\section{Kerangka Pemikiran}

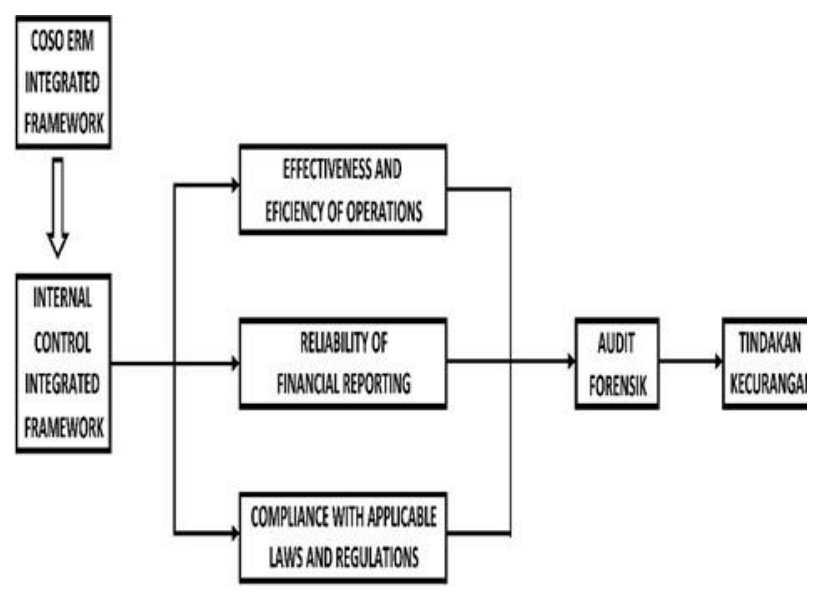

(Sumber: Data yang diolah)

\section{Tinjauan pustaka}

\section{a. Teori Stewardship}

Teori stewardship mendasarkan pada perilaku individu yang termotivasi untuk pemenuhan kebutuhan bersama dibandingkan kebutuhan individualnya dengan tujuan untuk mencapai sasaran organisasi yang telah disepakati. Teori ini 4. untuk memberikan pelayanan untuk kepentingan bersama. Oleh karena itu, teori ini berkaitan erat dengan psikologi individu dan sosiologi organisasi.Individu yang puas akan memberikan kontribusinya untuk kesuksesan organisasi (Donaldson et al., 1997). Dalam penerapan teori ini di perusahaan, para manajer atau eksekutif termotivasi untuk memberikan segala upaya yang terbaik kepada para prinsipalnya. Upaya terbaik dilakukan dengan cara meningkatkan kinerja perusahaan baik dari sisi operasional maupun finansial, bukan sebaliknya melakukan praktek manajemen laba, sehingga kesuksesan perusahaan dapat diraih. Kesuksesan organisasi tersebut pada akhirnya akan memaksimalkan kekayaan para pemegang saham (prinsipal).

Donaldson dan Davis (1991) menitikberatkan pada struktur kedudukan manajer dalam tingkatan organisasi perusahaan, artinya dengan kedudukan tanggung jawab dan otoritas yang lebih tinggi memberikan dorongan kepada manajer untuk bersikap pro terhadap perusahaan dengan memberikan loyalitas dan segenap kemampuan yang dimilikinya.

Donaldson et al. (1997) menguraikan lebih lanjut faktor psikologi dan faktor situasional (sosiologi) sebagai berikut:

1) Faktor Psikologi Individu

Dalam pandangan psikologi bahwa manusia adalah pusat peran (model of man) dimana akan terus mengalami perkembangan melebihi keadaan saat ini hingga mencapai tingkatan yang paling tinggi namun masih dibatasi oleh kemampuannya mencapai potensi yang penuh.

a) Motivasi

Motivasi didasari atas penghargaan penuh yang bisa dicapai (intrinsic reward) yang tidak bisa diubah-ubah dengan mudah, sehingga dapat mendorong individu untuk bekerja dengan kapasitas penuh demi 
pencapaian sasaran organisasi perusahaan. Penghargaan ini dapat berupa kesempatan yang diberikan organisasi kepada individu untuk bertumbuh, meningkatkan prestasinya dan mengaktualisasikan dirinya. Sejalan dengan landasan motivasi ini, Hackman dan Oldhan (1980) mengemukakan adanya karakteristik jabatan yang bersifat psykologis yaitu pengalaman individu dalam memahami pekerjaan, pengalaman individu dalam pertanggungjawaban hasil, dan pemahaman individu atas suatu hubungan nyata. Oleh karena itu, motivasi individu dalam bekerja dapat memberikan motivasi internal kepada individu melalui kepuasan kerja yang diperolehnya untuk lebih meningkatkan lagi kinerja pekerjaannya.

b) Identifikasi

Identifikasi didasari atas pandangan diri individu menjadi bagian tidak terpisahkan dari suatu organisasi untuk pencapaian misi dan visi organisasi. Para individu mengidentifikasikan diri dengan membayangkan penghargaan yang akan diterimanya atas kesuksesan organisasi yang didukungnya danjuga frustasi yang akan diterima bila organisasi menemui kegagalan. Dari pandangan identifikasi sosial, seorang manajer dipandang memiliki konsep dan citra pribadi karena erat kaitannya dengan atribut yang dimiliki organisasi dan keberhasilan organisasinya. Hal ini sejalan dengan pandangan Mowday et al. (1982) yang menyatakan bahwa setiap individu dalam organisasi bersifat kooperatif dalam bekerjasama dan berperilaku sebagai bagian tidak terpisahkan dengan organisasi tanpa terlalu banyak menuntut imbalan.

c) Penggunaan Kekuasaan

Kekuasaan merupakan aspek yang penting dan menjadi jembatan penghubung antara manajer dengan para prinsipalnya. Manajer termotivasi atas kekuasaan yang dipercayakan oleh prinsipal, sehingga menjadi daya gerak psykologi dalam mendukung pencapaian tujuan organisasi. Hal ini yang membedakan satu individu dengan individu yang lain dalam suatu organisasi atas dasar keahlian dan kelebihan kekuasaan individu dalam organisasi. Untuk mencapai hal ini, maka diperlukan adanya suatu imbalan dan pengakuan atas kekuasaan yang diterima individu sebagai bekal dalam melakukan pengawasan.

\section{d) Faktor Situasional}

Faktor situasional erat hubungannya dengan sosiologi dalam organisasi. Keberhasilan organisasi berdampak langsung terhadap maksimalisasi kekayaan prinsipal, sehingga membawa pengaruh maksimalisasi terhadap kelompok dalam manajemen, dan dalam lingkup kecil akan memaksimumkan kepentingan-kepentingan individu dalam organisasi tersebut.

e) Filosofi Manajemen

Filosofi manajemen berorientasi terhadap aspek keterlihatan hubungan antara individu organisasi dengan prinsipalnya, yaitu adanya suatu bentuk keterlibatan dari aspek ekonomi yang menciptakan pemenuhan sendiri yang konsisten (Argyris, 1973). Artinya bahwa filosofi manajemen mampumendorong individu organisasi untuk berperilaku dan bersikap sesuai yang diharapkan oleh manajemen.

f) Budaya

Budaya menekankan pada hal-hal lain pencapaian tujuan di luar tujuan kelompok yang sifatnya kolektif, artinya melekat secara inheren dalam diri individu organisasi yaitu kecenderungan individu untuk mengembangkan hubungan harmonis dengan prinsipalnya yang bukan didasari atas budaya individual. Dalam budaya individual tersebut berorientasi jangka pendek dari aspek ekonomis saja, namun dapat dimanfaatkan untuk mengevaluasi atas kegiatan bisnis organisasi.

\section{g) Rentang Kekuasaan}

Rentang kekuasaan merupakan perluasan dari kekuasaan individu-individu dalam organisasi, dan ada perbedaan antar tingkat kekuasaan tersebut dimana individu yang memiliki kekuasaan besar dapat mendukung hubungan leadership dengan tingkat kekuasaan di bawahnya. Walaupun terdapat perbedaan tingkat kekuasaan dalam organisasi namun terdapat penerimaan dan toleransi dari individu-individu organisasi yang terlibat di dalamnya.

h) Hubungan

Dalam hubungan, individu organisasi lebih menyukai adanya bentuk pengembangan diri atas tanggung jawab dalam organisasi maupun dalam aktualisasi dirinya yang didasarkan atas kepercayaan dan partisipasinya dalam organisasi. 


\section{b. Internal Control-Integrated Framework}

Pada tahun 1992 COSO merilis Internal Control-

Integrated Framework dan telah disetujui secara meluas. Diakui sebagai suatu kerangka yang memberikan petunjuk dalam merancang, mengimplementasikan pengendalian internal dan menguji efektifitas pengendalian internal. Dua puluh tahun kemudian, lingkungan bisnis telah berubah secara dramatis dan semakin komplek. Teknologi menjadi pemicu perubahan secara global. Pada saat yang sama pemangku kepentingan menghendaki suatu sistem pengendalian internal yang menjamin transfaransi dan akuntabilitas untuk mendukung pengambilan keputusan dan menciptakan tatalaksana yang baik dalam organisasi perusahaan. COSO berkeyakinan Internal Control-Integrated Framework mampu mengembangkan dan memelihara sistem pengendalian internal sedemikian, sehingga tujuan organisasi dapat dicapai dengan terus memperhatikan perubahan lingkungan.

Pada bulan September tahun 2012 The Committee of Sponsoring Organizations of the Treadway Commission (COSO) telah menerbitkan public exposure atas Internal control-Integrated Framework.

Internal Control-Integrated Framework tetap mempertimbangkan lima komponen pengendalian internal, dan juga mempertimbangkan kebijakan manajemen dalam merancang, mengimplementasikan, dan menguji efektifitas sistem pengendalian internal. Internal Control-Integrated Framework mempertimbangkan tujuan pelaporan keuangan dan juga informasi lain selain keuangan. Oleh karena itu Internal Control-Integrated Framework selalu memantau perubahan-perubahan dalam dunia usaha dan lingkungannya, termasuk: harapan untuk tatalaksana yang lebih baik, pemasaran global, perubahan hukum, aturan, dan regulasi, peningkatan kompetensi, dan akuntabilitas, perkembangan teknologi, dan penditeksian terjadinya fraud, suatu peluang untuk menciptakan laporan keuangan yang kredibel, memberi peluang untuk mengurangi risisko dalam mencapai tujuan organisasi.

Bagi manajemen Internal Control-Integrated Framework memberikan keyakinan yang memadahi dalam menjalankan organisasi, memberikan keyakinan yang memadahi bahwa tujuan organisasi akan tercapai, memberikan keyakinan yang memadahi bahwa risiko dapat terditeksi dan dapat dihindari, memberikan pemahaman yang memadahi mengenai efektifitas pengendalian internal, memberikan pemahaman yang memadahi mengenai kemungkinan mengeliminasi pengendalian internal yang tidak efektif.

Internal Control-Integrated Framework juga menjamin bahwa pengendalian internal dapat dilaksanakan dalam perusahaan kecil, menengah, besar, organisasi bermotif laba dan tidak bermotif laba, dan organisasi pemerintahan (lembaga negara). Tentu saja dengan penyesuaian-penyesuaian.

Kesimpulannya adalah: tujuan pengendalian internal menurut Internal Control-Integrated Framework:

1) Dari sudut pandang operasi: untuk menciptakan efisiensi dan efektivias operasi.

2) Dari sudut pandang pelaporan: meningkatkan kualitas pelaporan baik yang keuangan maupun non keuangan.

3) Dari sudut kepatuhan: meningkatkan kepatuhan terhadap peraturan dan perundang-undangan yang berlaku.

Lima komponen pengendalian internal terdiri dari:

1) Pengendalian lingkungan

Pengendalian lingkungan adalah satu set standar operasi, proses, dan struktur untuk membawa organisasi berjalan sesuai dengan kebijakan manajemen. Pimpinan puncak harus menciptakan nilai-nilai integritas untuk semua level. Termasuk juga menciptakan penghargaan dan sangsi kepada pimpinan dan karyawan di semua level bila melanggar integritas. Jalannya sutu sistem pengendalian internal sangat tergantung pada kemauan dan dukungan pimpinan puncak.

2) Pengendalian risiko

Setiap organisasi menghadapi risiko baik dari dalam maupun luar organsisasi yang berdampak pada gangguan terhadap capaian tujuan organisasi. Risiko tersebut berpotensi terjadi untuk setiap langkah aktivitas dan di semua level organisasi, sehingga pengendalian internal juga menciptakan bagaimana mengelola risiko. Peta risiko harus diciptakan sebelum 
suatu aktivitas dimulai, sehingga setiap risiko sudah terprediksi dan bila terjadi bukan merupakan kejutan.

3) Pengendalian aktivitas

Pengedalian aktivitas melalui kebijakan dan prosedur operasi standar akan sangat membantu manajemen dalam memitigasi atau menghindari risiko. Pengendaliaan aktivitas dibentuk untuk semua level organisasi baik manual maupun automatik, seperti otorisasi dan aproval, verifikasi, rekonsiliasi, dan review terhadap aktivitas bisnis.

4) Informasi dan komunikasi

Informasi diperlukan untuk suatu sistem pertanggungjawaban operasi organisasi yang lebih rendah ke yang lebih tinggi. Informasi disusun secara terstruktur dalam bentuk dan isi yang baku. Sedangkan komunikasi merupakan pemberian informasi yang tidak terstruktur dan bersifat interaktif antara pemberi informasi dan pemerima informasi. Bisa datang dari bawahan dan juga bisa datang dari atasan yang bersumber dari media cetak, media elektronik, dan bahkan informasi dari sejawat. Komunikasi yang baik di antara elemen dalam organisasi sering membawa manfaat bagi capaian tujuan.

5) Monitor aktivitas

Evaluasi secara ongoing atau ketika aktivitas berjalan atau evaluasi secara periodik terhadap aktivitas harus dilakukan untuk memastikan bahwa pengendalian internal berhasil mengendalikan aktivitas. Evaluasi ongoing mampu memberikan informasi yang tepat waktu, sehingga tindakan koreksi dapat dilakukan secepatnya. Kemampuan ini menyebabkan evaluasi ongoing lebih bermanfaat dibanding dengan evaluasi periodik. Evaluasi periodik lebih bermanfaat untuk koreksi aktivitas yang akan datang.

Ketika pengendalian internal telah ditetapkan efektif, Manajemen Senior dan Dewan Direksi mempunyai jaminan (assurance) yang masuk akal, yang menerangkan bahwa organisasi:

a) Mencapai tujuan operasi ketika standar dan kriteria dibangun oleh Legislator, Regulator, dan Penyusun Standar.

b) Memahami bahwa operasi telah dikelola secara efektif dan efisien ketika standar eksternal tidak ada.

c) Mempersiapkan laporan terkait kesesuaian dengan peraturan, regulasi, dan standar yang dibangun oleh Legislator, Regulator, dan Penyusun Standar, atau tujuan spesifik organisasi dan kebijakan yang terkait.

d) Patuh terhadap hukum dan perundang-undangan yang berlaku.

Internal Control-Integrated Framework memperhatikan semua komponen pengendalian internal sebagai kerangka yang cocok dan relevan pada semua bagian, sehingga membutuhkan semua komponennya tersedia dan berfungsi serta beroperasi bersama dalam pola kerja yang terintegrasi. Bila tidak bisa terpenuhi maka akan timbul ketidakefisienan.

\section{c. Enterprise Risk Management Integrated Framework}

The Committee of Sponsoring Organizations of the Treadway Commission (COSO) telah menerbitkan edisi terbaru di bulan Juni 2016 berupa public exposure atas Enterprise Risk Management Integrated Framework. Konsep ini memandang bahwa setiap kegiatan bisnis selalu akan diliputi oleh ketidakpastian yang dapat menimbulkan adanya risiko pada setiap kegiatan bisnisnya, sehingga diperlukan adanya penanganan risiko secara komprehensif dan terintegrasi antara penanganan satu risiko dan penanganan risiko lainnya. Sebagai contoh, atas suatu risiko yang berkaitan dengan permasalahan hukum yang dihadapi perusahaan akan berdampak terhadap reputasi perusahaan dan reputasi perusahaan berdampak terhadap kenaikan harga saham perusahaan di pasar modal.

\section{d. ERM dan Strategi}

Dalam model kerangka Enterprise Risk Management(ERM) digunakan dalam proses untuk menentukan dan mengidentifikasi strategi perusahaan yang cocok untuk diterapkan dengan memperhatikan berbagai faktor risikonya, kemudian risiko yang telah teridentifikasi tersebut dikelola dan dimitigasi sehingga tujuan perusahaan dapat dijamin pencapaiannya. Gambar 2 menunjukan strategi dan tujuan bisnis dengan mempertimbangkan risiko.

\section{Gambar 2}




\section{Strategi dan Tujuan Bisnis}

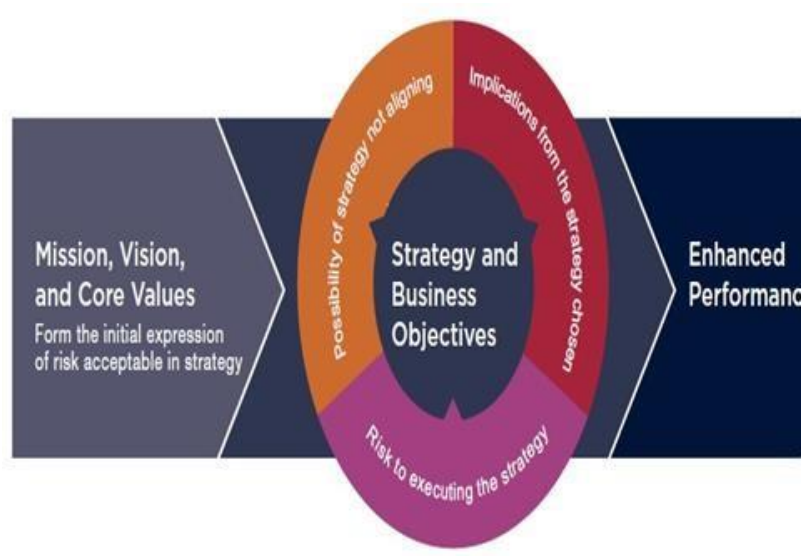

(Sumber : COSO Public Exposure, Juni 2016)

Pada misi dan visi yang ditetapkan oleh perusahaan memberikan pandangan atas tipe dan jumlah risiko yang dapat diterima oleh perusahaan. Keduanya dapat membantu organisasi untuk membangun batasanbatasan dan fokus bagaimana suatu keputusan yang diambil mempengaruhi strategi perusahaan. Perusahaan yang memahami dengan baik misi dan visinya maka akan dapat menetapkan strategi yang akan menghasilkan profil risiko yang diharapkan, dalam artian bahwa risiko-risiko yang terjadi merupakan risiko-risiko yang dapat diprediksi dan dimitigasi.

Hal yang harus digarisbawahi bahwa ERM ini tidak menciptakan strategi perusahaan melainkan hanya memberitahu mengenai risiko-risiko yang berhubungan dengan strategi yang dipertimbangkan dengan adopsi strateginya. Organisasi harus mengevaluasi bagaimana strategi yang dipilih dapat mempengaruhi profil risiko-risiko perusahaan khususnya atas profil tipe dan jumlah risiko organisasi yang dapat diekspos.

Ketika mengevaluasi risiko-risiko potensial yang timbul dari strategi, pihak Manajemen juga perlu mempertimbangkan asumsi kritis yang telah dibuat dari pilihan strategi yang telah ditetapkannya. Selain itu, organisasi juga dapat mempertimbangkan berbagai risiko yang timbul dari strategi yang dipilih tersebut. ERM memberikan pandangan yang berharga bagaimana perubahan sensitif atas asumsi mempunyai pengaruh sedikit atau bahkan pengaruh besar terhadap pencapaian tujuan perusahaan

Oleh karena itu, dengan diterapkannya ERM yang berbasis Integrated Framework maka perusahaan dapat menyelaraskan kebijakan dan strategi perusahaan dengan tingkat risiko yang dapat diterima (risk appetite) yang telah ditetapkan oleh Manajemen, sehingga dapat meningkatkan kwalitas pengambilan keputusan terhadap berbagai risiko yang dihadapi oleh perusahaan. Selain itu, dapat dimanfaatkan untuk mengidentifikasi berbagai risiko dan meminimalisir kerugian yang ditimbulkan atas berbagai risiko tersebut. Penerapan ERM ini bukan merupakan tujuan yang hendak dicapai oleh perusahaan, tetapi merupakan sebuah proses dalam mendukung penerapan tatakelola perusahaan yang baik (good corporate governance).

\section{e. Elemen-Elemen COSO ERM Integrated Framework}

Berkaitan dengan proses pengelolaan risiko, COSO ERM Integrated Framework memberikan panduan kepada perusahaan untuk menentukan sasarannya yang akan dicapai seperti nampak pada Gambar 3 berikut.

\section{Gambar 3}

Keterkaitan Sasaran, Komponen ERM, Unit Kerja

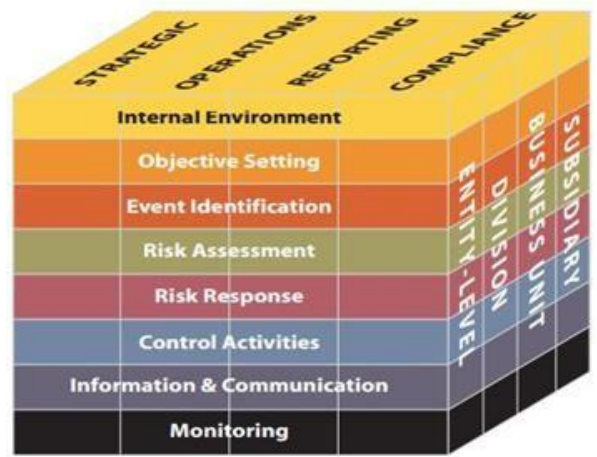

(Sumber : COSO Public Exposure, Juni 2016)

Terdapat 4 sasaran utama yang akan dicapai dalam penerapan COSO ERM Integrated Framework yaitu: 


\section{1) Strategis (Strategic)}

Sasaran strategi ditetapkan untuk memberikan dukungan dalam pelaksanaan dan pencapaian misi perusahaan, sehingga tujuan yang ditetapkan menjadi selaras dengan pelaksanaan operasional yang dijalankan oleh perusahaan.

2) Operasi (Operations)

Sasaran operasi diperlukan dalam pemanfaatan semua sumber daya yang dimiliki oleh perusahaan secara efektif dan efisien, sehingga sumber daya tersebut dapat lebih tepat guna.

3) Pelaporan (Reporting)

Sasaran pelaporan adalah dapat dipercayainya laporan yang diterbitkan perusahaan, khususnya untuk kepentingan pelaporan dengan pihak eksternal (stakeholder, shareholder).

\section{4) Kepatuhan (Compliance)}

Sasaran kepatuhan adalah terpenuhinya ketentuan dan persyaratan hukum dan regulasi yang berlaku, baik ketentuan dan persyaratan dari Pemerintah maupun Daerah.

Terdapat beberapa elemen ERM Integrated Framework dalam public exposure 2016 ini yang merupakan integrasi antara lima komponen pengendalian internal dengan ERM, yaitu:

1) Lingkungan Internal (Internal Environment)

Manajemen risiko yang dilakukan oleh perusahaan merupakan suatu bentuk pengelolaan risiko yang terjadi di dalam lingkungan internal perusahaan.

Terdapat berbagai elemen yang mempengaruhi lingkungan internal tersebut termasuk sistem nilai yang dianut oleh perusahaan, gaya kepemimpinan manajemen, pola penentuan keputusan, dan pola penentuan wewenang dan tanggung jawab manajemen. Hal ini berdampak terhadap bentuk tingkat risiko yang dapat diterima (risk appetite), tingkat toleransi risiko, budaya risiko, dan implementasi ERM.

2) Penetapan tujuan (Objective setting)

Tujuan harus ditetapkan lebih awal sebelum manajemen perusahaan memutuskan mengidentifikasi risiko-risiko yang telah ada, sehingga diharapkan risiko-risiko tersebut selanjutnya dapat dimitigasi, sehingga tujuan perusaahaan dapat tercapai. Tujuan perusahaan dapat diidentifikasi ke dalam tujuan yang sifatnya strategis, operasional, pemenuhan, dan pelaporan. Hal ini dapat memungkinkan manajemen berpusat keempat aspek tujuan perusahaan tersebut dalam proses ERM.

3) Identifikasi risiko (Event identification)

Seluruh kejadian baik yang datangnya dari dalam perusahaan (internal) maupun dari luar perusahaan (eksternal) yang berpotensi mempunyai pengaruh terhadap sasaran yang hendak capai maka harus diidentifikasi berbagai risiko yang dapat timbul. Identifikasi risiko ini dapat dilakukan dengan berbagai cara, diantaranya melihat analisa kecenderungan (tren), analisa atas kejadian masa lalu (historis), ataupun dengan analisa proyeksi masa depan.

4) Penilaian risiko (Risk assesment)

Dalam penilaian risiko, perusahaan melakukan penilaian berbagai tingkat dan besarnya risiko yang dapat berpengaruh terhadap pencapaian tujuan perusahaan. Risiko-risiko tersebut dapat ditentukan berdasarkan kemungkinan keterjadiannya (likelihood) dan dampak yang ditimbulkannya sehingga dapat diperhitungkan mitigasi penyelesaiannya dimulai dari tingkat dan besarnya risiko yang paling tinggi sampai terendah.

5) Perlakuan risiko (Risk response)

Tahap selanjutnya melakukan perlakuan risiko yang tepat untuk setiap risiko yang terjadi, menentukan tingkat toleransi risiko tersebut, dan menentukan berbagai alternatif penyelesaian risiko-risiko yang teridentifikasi. Terdapat beberapa perlakuan risiko yang timbul yaitu menghindar, menerima, mengurangi, dan membagi risiko kepada berbagai pihak.

6) Aktivitas pengendalian (Control activities) Dalam aktivitas pengendalian dilakukan penerapan atas kebijakan dan prosedur yang telah ditetapkan perusahaan yang maksudkan untuk memastikan bahwa risiko-risiko telah diperlakukan secara efektif, sehingga proses mitigasi terlaksana dengan baik. Tahap selanjutnya menyusun dan mengembangkan sistem pengembangan perusahaan yang terintegrasi.

7) Informasi dan komunikasi (Information and communication)

Informasi yang berkaitan dengan pencapaian tujuan 
perusahaan diidentifikasi apakah berdampak langsung atau tidak, dikelompokkan ke dalam berbagai jenisnya, dan didistribusikan atau dikomunikasikan melalui media komunikasi yang tepat dengan waktu yang tepat pula sehingga setiap individu perusahaan dapat menjalankan tugas dan tanggung jawabnya dengan lebih baik.

8) Pemantauan (Monitoring)

Tahap terakhir yaitu melakukan pemantauan atas semua aktivitas pengendalian risiko yang telah dilakukan untuk menjamin bahwa risiko-risiko telah dimitigasi dengan baik. Selain itu, mempertimbangkan juga data-data yang diperoleh baik berupa data historis, data saat ini, maupun data berupa peramalan masa depan. Data historis dimaksudkan untuk melacak kinerja masa lalu terkait pencapai target, rencana, dan ekspektasinya. Data saat ini menyajikan informasi tambahan d

an data masa depan untuk penyempurnaan analisa informasi. Dari hasil pemantauan selanjutnya dievaluasi kembali untuk penyempurnaan lebih lanjut kemudian dikembangkan untuk menghasilkan pelaksanaan sistem organisasi yang lebih baik.

\section{f. Program dan Pengendalian Anti-fraud} (Lembaga Diklat: Pendidikan dan Pelatihan Audit Firensik 2017 buku III hal 37 sd 43)

Pada tahun 2002, Fraud Task Force dari AICPA mengadakan studi untuk menyusun pedoman yang dapat membantu pencegahan dan pendeteksian fraud. Studi yang didukung oleh Association of Certified Fraud Examiners (ACFE), AICPA, IIA, dan beberapa organisasi profesi lainnya tersebut menghasilkan dokumen berjudul Management Anti fraud Programs and Controls. Dokumen mengungkapkan ukuranukuran (measures) yang perlu diterapkan dalam upaya mencegah, menangkal, dan mendeteksi fraud. Ukuranukuran tersebut terdiri atas 3 unsur dasar yang harus diimplementasikan dan dimonitor, yaitu:

1) Menciptakan dan memelihara kultur kejujuran dan etika yang tinggi

2) Melaksanakan evaluasi risiko fraud dan menerapkan proses, prosedur, dan pengendalian yang diperlukan untuk mengurangi risiko dan peluang fraud.

3) Mengembangkan proses pengawasan

Masing-masing unsur tersebut dapat dijabarkan sebagai berikut:

1) Menciptakan dan memelihara kultur kejujuran dan etika yang tinggi

Unsur ini dilaksanakan dengan:

a) Menciptakan keteladanan manajemen

Manajemen tidak dapat mengharapkan pegawai akan berlaku etis jika manajemen sendiri tidak bertindak etis. Oleh karena itu, manajemen harus menjadi teladan perilaku etis dalam organisasi.

b) Menciptakan lingkungan kerja yang positif Beberapa faktor yang dapat digunakan untuk menciptakan lingkungan kerja yang positif dan mengurangi risiko fraud adalah:

1. Sistem penghargaan dan pengakuan (reward \& recognition)

2. Pemberian kesempatan yang sama bagi seluruh pegawai

3. Orientasi pada tim (team-oriented) dan kebijakan pengambilan keputusan secara musyawarah (collaborative decision making)

4. Program pemberian kompensasi yang diadministasikan secara professional

5. Program pelatihan dan prioritas organisasi pada pengembangan karier

c) Menerima dan mempromosikan pegawai dengan tepat

Organisasi harus memiliki prosedur yang efektif untuk meminimalkan kemungkinan menerima dan mempromosikan pegawai yang memiliki tingkat kejujuran yang rendah, khususnya untuk posisi yang membutuhkan kepercayaan. Prosedur tersebut meliputi:

1. Memeriksa latar belakang calon yang akan diterima sebagai pegawai atau dipromosikan pada posisi yang membutuhkan kepercayaan

2. Melakukan pengecekan latar belakang, pendidikan, dan referensi dari calon

3. Mengadakan pelatihan secara periodik mengenai nilai-nilai organisasi dan kode etik

4. Dalam review kinerja yang regular dimasukkan unsur evaluasi atas kontribusi masing-masing pegawai 
dalam membantu menciptakan lingkungan kerja yang positif sesuai nilai-nilai organisasi kode etik

5. Evaluasi terus menerus atas ketaatan terhadap nilai-nilai organisasi dan kode etik dan penyimpangan yang terjadi segera ditangani

d) Pelatihan

Pelatihan mencakup materi sadar fraud (fraud awareness). Untuk penyegaran, pelatihan secara periodik perlu diulang-ulang.

e) Konfirmasi

Pegawai yang termasuk dalam jajaran manajemen senior, fungsi keuangan, dan pegawai pada bidangbidang yang rentan terhadap perilaku tidak etis diharuskan menandatangani pernyataan kode etik paling tidak setahun sekali.

f) Disiplin

Penerapan tindakan disiplin fraud akan memberikan efek penangkalan yang efektif dan menunjukkan bahwa organisasi memiliki komitmen terhadap lingkungan dengan standar etik yang tinggi dan penuh integritas.

2) Melaksanakan evaluasi risiko fraud dan menerapkan proses, prosedur, pengendalian yang diperlukan yang diperlukan untuk mengurangi risiko dan peluang fraud

Organisasi harus secara proaktif mengurangi peluang fraud dengan mengidentifikasi dan mengukur risiko fraud, mengurangi risiko fraud yang teridentifikasi, serta menerapkan dan memantau pengendalian internal yang bersifat preventif dan detektif.

a) Mengidentifikasikan dan mengukur risiko fraud Proses penilaian risiko fraud harus mempertimbangkan kerentanan organisasi terhadap tindakan fraud dan dampak tindakan fraud terhadap organisasi. Dalam mengidentifikasi risiko fraud diperhatikan pengaruh karakteristik organisasi, industri, dan negara.

b) Mengurangi risiko fraud

Risiko fraud dapat dikurangi atau dihilangkan dengan melakukan perubahan atas aktivitas dan proses organisasi. Misalnya menjual satu segmen operasi tertentu atau menjual cabang perusahaan pada lokasi tertentu untuk menghilangkan risiko fraud yang tidak dapat dihindarkan. c) Menerapkan dan memantau pengendalian internal

Manajemen harus melakukan evaluasi untuk meyakinkan bahwa pengendalian internal yang efektif telah diterapkan terutama pada bidang-bidang yang memiliki risiko fraud yang tinggi.

\section{3) Mengembangkan proses pengawasan}

Organisasi harus menjalankan pengawasan. Pengawasan dapat dilakukan oleh internal organisasi atau pihak eksternal, di bawah pengawasan komite audit.

a. Komite audit melakukan evaluasi atas upaya manajemen dalam mengidentifikasi risiko fraud, mengimplementasikan ukuran-ukuran anti-fraud, dan menciptakan keteladanan manajemen.

b. Manajemen bertanggung jawab mengawasi aktivitas pegawai dengan menerapkan dan memantau proses dan pengendalian internal

c. Auditor internal membantu menangkal fraud dengan melakukan pemeriksaan dan evaluasi atas kecukupan dan efektivitas sistem pengendalian internal, sejalan dengan potensi risiko yang terkandung dalam berbagai segmen operasi organisasi

d. Certified Fraud Examiners (CFE) dapat membantu komite audit dalam mengevaluasi penilaian risiko fraud dan penerapan ukuran-ukuran pencegahan fraud. CFE juga dapat membantu melakukan pemeriksaan atas laporan/pengaduan mengenai fraud.

g. Hasil-hasil Penelitian Terdahulu

Hasil penelitian yang relevan diuangkap untuk memperkuat penulisan ini. Penelitian sebagaai berikut meliputi berbagai variabel terkait dan analisanya seperti nampak Tabel 1 berikut ini: 
Tabel 1

\section{Hasil-Hasil Penelitian}

\begin{tabular}{|c|c|c|c|c|c|}
\hline No. & $\begin{array}{l}\text { Nama } \\
\text { dan } \\
\text { Tahun }\end{array}$ & Judul & $\begin{array}{c}\text { Objek dan } \\
\text { Subjek }\end{array}$ & $\begin{array}{c}\text { Teknik } \\
\text { Pengorganisasi } \\
\text { dan Analisis Data }\end{array}$ & Hasil Penelitian \\
\hline 1. & $\begin{array}{l}\text { Hall } \\
(2017)\end{array}$ & $\begin{array}{l}\text { Fraud Detection } \\
\text { and The Internal } \\
\text { Audit. }\end{array}$ & $\begin{array}{l}\text { Obyek: } \\
\text { Deteksi } \\
\text { kecurangan. } \\
\text { Subjek: Peran } \\
\text { manajemen } \\
\text { dan internal } \\
\text { auditor. }\end{array}$ & $\begin{array}{l}\text { Teknik: } \\
\text { Kualitatif. } \\
\text { Analisis Data: } \\
\text { Observasi dan } \\
\text { wawancara. }\end{array}$ & $\begin{array}{l}\text { (1) Perlunya } \\
\text { keahlian teknik } \\
\text { audit kecurangan, } \\
\text { (2) perlunya } \\
\text { pendidikan } \\
\text { berkelanjutan. }\end{array}$ \\
\hline 2. & $\begin{array}{l}\text { Salifou } \\
\text { (2015) }\end{array}$ & $\begin{array}{lr}\text { Analysis of } & \text { The } \\
\text { Efectiveness } & \text { of } \\
\text { COSO's } & \text { ERM } \\
\text { Model } & \text { on } \\
\text { Organization } & \\
\text { Strategy, } & \\
\text { Competitive } \\
\text { Advantage, and } \\
\text { Value: A Qualitatif } \\
\text { Study. }\end{array}$ & $\begin{array}{l}\text { Obyek: } \\
\text { Strategi } \\
\text { organisasi, } \\
\text { strategi, dan } \\
\text { nilai. } \\
\text { Subjek: } \\
\text { Penerapan } \\
\text { COSO ERM } \\
\text { Model. }\end{array}$ & $\begin{array}{l}\text { Teknik: } \\
\text { Eksplorasi } \\
\text { Kualitatif. } \\
\text { Analisis Data: } \\
\text { Wawancara. }\end{array}$ & $\begin{array}{l}\text { Pengaruh } \\
\text { signifikan atas } \\
\text { penerapan COSO } \\
\text { ERM Model. }\end{array}$ \\
\hline 3. & $\begin{array}{l}\text { Tseng } \\
\text { (2007) }\end{array}$ & $\begin{array}{lr}\text { Internal } & \text { Control, } \\
\text { Enterprise } & \text { Risk } \\
\text { Management, and } \\
\text { Firm Performance. }\end{array}$ & $\begin{array}{l}\text { Obyek: } \\
\text { Internal } \\
\text { control, ERM, } \\
\text { kinerja } \\
\text { perusahaan. } \\
\text { Subjek: } \\
\text { Sarbaney } \\
\text { Oxley. }\end{array}$ & $\begin{array}{l}\text { Teknik: } \\
\text { Kuantitatif } \\
\text { Analisis Data: } \\
\text { Descriptive dan } \\
\text { univariate. }\end{array}$ & $\begin{array}{l}\text { Adanya } \\
\text { peningkatan } \\
\text { kebutuhan ERM } \\
\text { setelah } \\
\text { diberlakukannya } \\
\text { Sarbaney Oxley. }\end{array}$ \\
\hline
\end{tabular}

meningkatkan keahliannya dalam deteksi kecurangan

Adapun secara lebih rinci, hasil penelitian diuraikan perlu dilakukan adanya pelatihan berkelanjutan.

sebagai berikut:

1) Hall (2017) melakukan penelitian dengan judul Fraud Detection and The Internal Audit. Tujuan dari penelitian tersebut adalah untuk mengidentifikasi peranan manajemen vs. peranan internal auditor dalam mendeteksi kecurangan, menentukan kebutuhan peningkatan kompetensi yang dibutuhkan internal auditor dalam menjalankan pelaksanaan tugas deteksi kecurangan yang terjadi, serta mengusulkan pemanfaatan audit internal oleh manajemen. Dari hasil identifikasi yang dilakukan, peneliti menemukan bahwa diperlukan adanya keahlian teknis internal auditor terhadap kecurangan yaitu adanya fraud examiner dan fraud investigator karena peran dan tanggung jawabnya dalam deteksi kecurangan yang terjadi di perusahaan. Selain itu untuk terus
2) Salifou (2015) melakukan penelitian dengan judul Analysis of The Efectiveness of COSO's ERM Model on Organization Strategy, Competitive Advantage, and Value: A Qualitatif Study. Hasil penelitian menunjukkan pengaruh positif yang signifikan penerapan COSO ERM Model dalam hal strategi organisasi, keunggulan kompetitif, dan peningkatan nilai. Penelitian ini juga mendorong untuk penelitian berikutnya untuk meneliti efektivitas COSO ERM Model termasuk eksplorasi atas integrasi pengendalian eksternal bersama dengan pengendalian internal ke dalam kerangka COSO ERM.

3) Tseng (2007) melakukan penelitian dengan judul Internal Control, Enterprise Risk Management, and Firm Performance. Hasil penelitian menunjukkan adanya suatu usaha yang dibangun SOX (SarbaneyOxley) untuk mengkatkan pengendalian 
internal, dan adanya peningkatan kebutuhan untuk ERM (Enterprise Risk Management) karena sistem pengendalian internal mendasarkan pada kecukupan dan analisis komprehensif dari risiko perusahaan yang lebih luas.

Dari penjabaran hasil ketiga peneliti di atas dapat disimpulkan bahwa:

1) Hall (2017), peneliti menemukan bahwa diperlukan adanya keahlian teknis internal auditor terhadap kecurangan yaitu adanya fraud examiner dan fraud investigator karena peran dan tanggung jawabnya dalam deteksi kecurangan yang terjadi di perusahaan.

2) Salifou (2015), penelitian menunjukkan pengaruh positif yang signifikan penerapan COSO ERM Model dalam hal strategi organisasi, keunggulan kompetitif, dan peningkatan nilai.

3) Tseng (2007), penelitian menunjukkan adanya suatu usaha yang dibangun SOX (Sarbaney-Oxley) untuk mengkatkan pengendalian internal, dan adanya peningkatan kebutuhan untuk ERM (Enterprise Risk Management) karena sistem pengendalian internal mendasarkan pada kecukupan dan analisis komprehensif dari risiko perusahaan yang lebih luas.

Penelitian-penelitian terdahulu yang dilakukan bersifat terpisah-pisah ke dalam aspek efektivitas pengendalian internal, tindakan kecurangan, model ERM, dan kinerja perusahaan. Dalam tulisan ini, penulis berusaha menggabungkan keempat aspek yang terpisah tersebut ke dalam satu topik penulisan yaitu mengenai implementasi COSO ERP Integrated Framework dalam mendukung audit forensik untuk pencegahan kecurangan.

\section{Kesimpulan}

Terdapat beberapa elemen ERM Integrated Framework dalam public exposure 2016 ini yang merupakan integrasi antara lima komponen pengendalian internal dengan ERM, sehingga apabila komponen-komponen pengendalian internal diintegrasikan dengan ERM dan diimplementasikan dalam organisasi akan memberikan jaminan bagi manajemen bahwa tujuan organisasi akan tercapai secara efektif dan efisien termasuk mencegah terjadinya risiko fraud. Elemen-elemen pengendalian internal dan integrasinya dengan ERM adalah:

1) Lingkungan Internal (Internal Environment). Manajemen risiko yang dilakukan oleh perusahaan merupakan suatu bentuk pengelolaan risiko yang terjadi di dalam lingkungan internal perusahaan.

2) Penetapan Tujuan (Objective Setting). Tujuan ditetapkan lebih awal sebelum manajemen organisasi memutuskan mengidentifikasi risiko-risiko yang telah ada, sehingga diharapkan risiko-risiko tersebut selanjutnya dapat dimitigasi, sehingga tujuan perusahaan dapat tercapai.

3) Identifikasi Risiko (Event Identification). Seluruh kejadian baik yang datangnya dari dalam organisasi (internal) maupun dari luar organisasi (eksternal) yang berpotensi mempunyai pengaruh terhadap sasaran yang hendak capai maka harus diidentifikasi berbagai risiko yang dapat timbul.

4) Penilaian Risiko (Risk Assesment). Dalam penilaian risiko, organisasi melakukan penilaian berbagai tingkat dan besarnya risiko yang dapat berpengaruh terhadap pencapaian tujuan organisasi.

5) Perlakuan Risiko (Risk Response). Tahap selanjutnya melakukan perlakuan risiko yang tepat untuk setiap risiko yang terjadi, menentukan tingkat toleransi risiko tersebut, dan menentukan berbagai alternatif penyelesaian risiko-risiko yang teridentifikasi.

6) Aktivitas Pengendalian (Control Activities). Dalam aktivitas pengendalian dilakukan penerapan atas kebijakan dan prosedur yang telah ditetapkan organisasi yang maksudkan untuk memastikan bahwa risiko-risiko telah diperlakukan secara efektif.

7) Informasi dan Komunikasi (Information and Communication). Informasi yang berkaitan dengan pencapaian tujuan organisasi diidentifikasi apakah berdampak langsung atau tidak.

8) Pemantauan (Monitoring). Tahap terakhir yaitu melakukan pemantauan atas semua aktivitas pengendalian risiko yang telah dilakukan untuk menjamin bahwa risiko-risiko telah dimitigasi dengan baik.

9) Organisasi harus menjalankan pengawasan. Pengawasan dapat dilakukan oleh internal organisasi 
atau pihak eksternal, di bawah pengawasan komite audit.

10) Auditor internal membantu menangkal fraud dengan melakukan pemeriksaan dan evaluasi atas kecukupan dan efektivitas sistem pengendalian internal, sejalan dengan potensi risiko yang terkandung dalam berbagai segmen operasi.

\section{References}

Asosiasi Auditor Internal. (2016). Standar Profesi Auditor Internal.

Committee of Sponsoring Organizations of the Treadway Commission. (2016).COSO ERM Integrated Framework : Aligning Risk with Strategy and Performance. Public Exposure Juni 2016.

Committee of Sponsoring Organizations of the Treadway Commission. (2012). Internal Control Integrated Framework. Public Exposure September 2012.

Donaldson et al. (1997). Toward a Stewardhip Theory of Management. Academy of Management Review. Vol. 22 (1), page 22-47.

Donaldson, Lex dan James H. Davis. (1991). Stewardship Theory or Agency Theory : CEO Governance and Shareholder Returns. Australian Journal of Management. Vol.16, page 49-64.

Hall, Xylia M. (2017). Fraud Detection and The Internal Control. Proquest, Number 10255005.

Hackman, J. R. dan Oldham, G. R. (1980). Work redesign. Reading, MA: Addison-Wesley.

Lee et al. (2009). Principles and Contemporary Issues in Internal Auditing. Second Edition. McGrawHill (Malaysia) Sdn. Bhd.

Lincoln, Ivonna S. dan Egon G. Cuba. 1985. Naturalistic Inquiry. Beverly Hills: Sage Publications.

Mowday et al. (1982). Employee Organization Lingkages: The Psychology of Commitment, Absenteeism and Turnover. London: Academic Press Inc.

Salifou, Daniel A. (2015). Analysis of The Efectiveness of COSO's ERM Model on
Organization Strategy, Competitive Advantage, and Value: A Qualitatif Study. Proquest, Number 10002584

Tseng, Chih-Yang. (2007). Internal Control, Enterprise Risk Management, and Firm Performance. Dissertation submitted to the Faculty of the Graduate School of theUniversity of Maryland, College Park, in partial fulfillmentof the requirements for the degree of Doctor of Philosophy.

http://haviafotokopi.blogspot.co.id/2015/11/cara-men ulis-kutipan-dari-internalet.html

https://csuryana.wordpress.com/2010/03/25/data-dan-j enis-data-penelitian/ 